\title{
Communication policies for innovation financed with public funds in Spain: the experts' view
}

\author{
María J. Vilaplana-Aparicio; Marta Martín-Llaguno; Mar Iglesias-García
}

Nota: Este artículo se puede leer en español en:

http://www.elprofesionaldelainformacion.com/contenidos/2020/mar/vilaplana-martin-iglesias_es.pdf

How to cite this article:

Vilaplana-Aparicio, María J.; Martín-Llaguno, Marta; Iglesias-García, Mar (2021). “Communication policies for innovation financed with public funds in Spain: the experts' view". Profesional de la información, v. 30, n. 3, e300308.

https://doi.org/10.3145/epi.2021.may.08

Manuscript received on $26^{\text {th }}$ September 2020 Accepted on $8^{\text {th }}$ January 2021

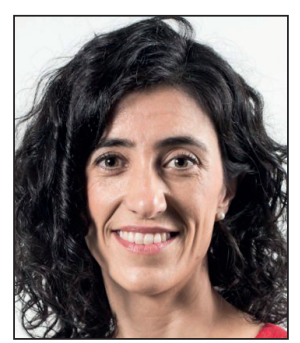

María J. Vilaplana-Aparicio $\square$ https://orcid.org/0000-0002-6373-8454

Universidad de Alicante

Departamento de Comunicación y

Psicología Social

Campus Sant Vicent del Raspeig, Ap. 99.

03080 Alicante, Spain

maria.vilaplana@ua.es

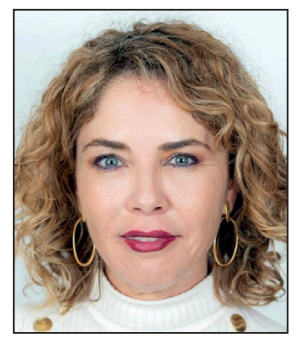

Marta Martín-Llaguno

https://orcid.org/0000-0003-2252-5505

Universidad de Alicante

Departamento de Comunicación y

Psicología Social

Campus Sant Vicent del Raspeig, Ap. 99.

03080 Alicante, Spain

marta.martin@ua.es

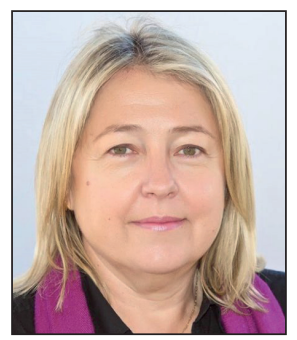

\author{
Mar Iglesias-García \\ https://orcid.org/0000-0001-7926-5746 \\ Universidad de Alicante \\ Departamento de Comunicación y \\ Psicología Social \\ Campus Sant Vicent del Raspeig, Ap. 99. \\ 03080 Alicante, Spain \\ mar.iglesias@ua.es
}

\begin{abstract}
Companies that receive public funds for research and development and technological innovation (R\&D\&I) projects must comply with certain communication obligations in accordance with relevant Spanish and European laws. The aim of this work is to assess these requirements (including their advantages and limitations) based on the opinion of experts in the field. Interviews were conducted with R\&D\&I managers in national and regional agencies; innovation, transparency, and scientific dissemination specialists; and company directors. The results confirm the value of communicating innovation, in accordance with the current trends of innovation dissemination and the principles of transparency. Experts consider that the required communication requirements are insufficient and that their means and formats must be adapted to enhance the dissemination of innovation and improve transparency by promoting accessible content in a unified repository. They propose the measurement and assessment of the social impact of subsidized projects, as well as the possibility of subsidizing communication actions, as in European projects. Moreover, there is an urgent need to standardize the communication obligations of all proposals.
\end{abstract}

\section{Keywords}

Communication; Information; Dissemination; Transparency; Science dissemination; Communication plan; Media; Innovation; R\&D\&I; Grants; Public funds. 


\section{Introduction}

Research and development and technological innovation (R\&D\&I) plays a fundamental role in the competitiveness and progress of society, acting as the main basis for growth and social well-being in contemporary culture (Leibowicz, 2018; Iturrate-Meras, 2019). Public administrations are working to encourage companies to invest in R\&D\&I, and in both Europe and its different member states, plans to promote innovation are structured with an outstanding financial funding (in 2018, 1.24\% of GDP was allocated in Spain, and 2.19\% in Europe, on average) ${ }^{1}$.

Innovation dissemination plays an essential role in the R\&D\&I process since the key is not only to create products but also for them to reach society. However, it should be noted that the social impact of an innovation adopted by segmented or global audiences is neither measured nor valued (Pedreño-Muñoz; Moreno-Izquierdo, 2020).

In public policies promoting business research and development (R\&D), communication is also essential since it guarantees transparency during the allocation of funds, a crucial process in which citizens can identify the destination of their tax money. The focus of this article is the analysis of R\&D\&I communication from a dual perspective: as an engine for dissemination and as a mechanism for transparency.

\section{Theoretical framework}

\subsection{Dissemination of innovation and communication}

The innovation dissemination process has attracted attention from many experts. As early as 1962, Everett Rogers tried to determine which kinds of discoveries spread through a social system, how, and why. In this way, he developed his theory of the dissemination of innovation, focused on the analysis of the

"process by which an innovation is communicated through certain channels over time among the members of a social system. It is a special type of communication, in that the messages are concerned with new ideas" (Rogers, 1962, p. 5).

Subsequently, many authors have validated mathematical models measuring innovation dissemination. Following Rogers' original article, Bass's (1969) contribution became the point of reference for numerous investigations (Turk; Trkman, 2012; Ratcliff; Doshi, 2016; Fan; Che; Chen, 2017; Horvat; Fogliano; Luning, 2020) as cited in several bibliographic reviews (Mahajan; Muller; Bass, 1990; Baptista, 1999; Meade; Islam, 2006; Peres; Muller; Mahajan, 2010; Dhakal; Min; Lim, 2019; Gruenhagen; Parker, 2020). As a result, the important combination of advertising and word of mouth in repeat purchases became known (Dodson; Muller, 1978). Horsky and Simon (1983) showed that a company can control the evolution of their sales curve through advertising and that the initial effort in this regard is essential. Extending this model, Monahan (1984) tried to determine the optimal advertising rate, and one year later, Kalish (1985) identified the importance of this rate in combination with the price factor.

Simon and Sebastian (1987) pointed to the influence that advertising and communication have on the demand of imitators. Subsequently, Dockner and Jørgensen (1988) stated that the coefficients of innovation and imitation are dependent on communication, a fact corroborated by Tanny and Derzko (1988). The perceptions of innovation adopters have varied over time in parallel with their assessment of internal and external forces (Mahajan; Muller; Bass, 1990) such as price and advertising (Mesak; Clark, 1998; Bass; Krishnan; Jain, 1994; Chaudhary; Jha, 2018). Similarly, Mehta, Chaudhary, and Kumar (2020) addressed the need for an optimal promotional effort, clarifying that, given the increasing globalization of the market and consumer groups, innovation communication is also conditioned by adequate segmentation, which allows for differentiated communications.

The communication-innovation interaction has been evaluated in publications by Kaiser (2005), demonstrating how the strategic interaction between these two variables depends on their associated benefits. Companies substitute communication for R\&D when the returns associated with the latter are perceived as greater than those of the former, although both can be seen as strategic complements.

Burmester et al. (2015) highlight the value of other communication formulas aside from advertising in innovation dissemination. Along the same vein, Ye, Jha, and Desouza (2015) point out the different communication strategies required during the various stages of the innovation process.

Consistent with our research, Mea et al. $(2016$, p. 1) review the communication strategies of companies receiving EU funds and highlight the need for companies to develop an effective dissemination strategy before the start of any project. They state that companies "must have a clear objective" and "identify the target groups"

to be able to use the tools consistent with the aim and objectives. In their strategy, Mea et al. (2016) combine traditional media, such as scientific publications or participation in conferences, with new media such as social networks or smartphone applications. After assessing each method's efficacy, they conclude that publishing on the internet or Twitter is very useful, while utilizing apps or Facebook has only a moderate impact. Conversely, some research (Ekblom, 2018) has demonstrated the appropriateness of media platforms such as Facebook to disseminate project results.

In the relevant work carried out by Cavenaile and Roldan (2019), the authors conclude that lower investment in advertising is associated with lower investment in R\&D and slower economic growth. Based on the understanding that spen- 
ding on advertising and innovation are substitutes, the authors demonstrate that innovation subsidies are more effective in an economy that includes advertising than in one that does not. The findings of $\mathbf{X u}$, Liu, and Chen (2019) can be added to this: after studying the behavior of companies in South Korea, they determine that company size also influences the relationship between advertising and R\&D.

Finally, several experts point to the need to standardize terminology and information in this field to achieve more efficient communication of innovative products (Bahrami; Atkin; Landin, 2019). This facilitates the comparison of products and reduces any uncertainty associated with innovation (Egyedi; Ortt, 2017).

On the basis of these previous works, it can be deduced that innovation communication increases the probability of that innovation being adopted and conditions the relative success or failure of a project.

\subsection{Transparency in the allocation of funds}

The concept of transparency is complex because

"it can mean many things to many people" (Grimmelikhuijsen et al., 2019, p. 3).

Grimmelikhuijsen et al. make an approximation and define it as

"the availability of information about an organization or actor that allows external actors to monitor the internal functioning or performance of that organization" (Grimmelikhuijsen et al., 2013, p. 576).

In this article, we place special emphasis on the transparency of public policies. Similarly, Heald (2006) and Grimmelikhuijsen and Welch (2012) identify different areas in which the government determines the level of transparency:

- Transparency of the decision-making process: the degree of openness about the steps taken to reach a decision, as well as the justification for that decision.

- Transparency of policy content: the information disclosed by the government about a policy.

- Transparency of policy results/effects: the provision and timeliness of information on the effects of a policy.

Transparency contributes to an increase in participation, an improvement in management, and a reduction in corruption (Cucciniello; Porumbescu; Grimmelikhuijsen, 2017). This interest in transparency is motivated mainly by the proliferation of the concept of open government (Geiger; Von-Lucke, 2012; Wirtz; Birkmeyer, 2015). Along these lines, Heckmann (2011) affirms that the concept of open government involves enhancing the transparency and accountability of all public affairs. This acquires significant relevance when considering citizen demands for more information, especially in matters related to taxation, security, and government (Piotrowski; Van-Ryzin, 2007). For this reason, governments work to reduce the current gap between administrations and citizens and try to increase citizen participation (Wijnhoven; Ehrenhard; Kuhn, 2015).

In the academic context, a positive correlation between transparency and innovation has been demonstrated. The works of Tomás-Lopes and Marques-Serrasqueiro (2017) are worth highlighting as they demonstrate the effective relationship between the level of transparency in a country and R\&D spending. Brown and Martinsson (2017) found that a higher level of transparency can lead to an increase in external capital for innovative projects. Zhong (2018) points out that transparency improves the conversion of R\&D into patents. Similarly, Wu et al. (2019) argue that, when company transparency is high, exchanges with community stakeholders are strengthened, and these exchanges can further expand innovation efforts.

As discussed by Brown and Martinsson (2017), transparency not only generates benefits but also facilitates investment. Furthermore, it can make it difficult for innovative companies to hide their activities from competitors, hindering the subsequent registration of patents. These arguments coincide with those of Bloom, Van-Reenen, and Williams (2019), who demonstrate how transparency could attract the attention of competitors, aiding the duplication of the innovation and obstructing the company's ability to monetize it in its entirety. This is a relevant question considering that R\&D is a longterm, high-risk investment (Martin; Scott, 2000; Hall, 2002) that carries high failure rates (Baysinger; Kosnik; Turk, 1991).

The issue of transparency in the allocation of funds is a concern for both the European Commission and the member states (Cini, 2008). Consequently, notable efforts have been made to increase the information available to reduce fraud, especially in countries such as Spain, which have approved transparency legislation and implemented protocols (Casadesús-de-Mingo; Cerrillo-Martínez, 2018). Pacios, Vianello-Osti, and Rodríguez-Bravo delve into this issue and analyze the published information related to Spanish universities' research projects, concluding that, although the law is complied with, such information

"is not individualized and is rarely linked to the results (articles, patents, papers, etc.) that would allow knowledge to be shared" (Pacios; Vianello-Osti; Rodríguez-Bravo, 2016, p. 722).

Transparency regarding the results or effects can provide information about the impact of public policies (Grimmelikhuijsen; Welch, 2012) and how they contribute to the well-being of society. Therefore, since citizens demand greater transparency, it is essential to implement a balanced innovation communication policy (Piotrowski; Van-Ryzin, 2007); however, excessive release of results may discourage companies from applying for different subsidies. 


\subsection{Regulation of R\&D\&I in the European and national framework}

\subsubsection{Public R\&D\&I policies in Europe and Spain}

To understand the need for public intervention in R\&D\&I policies, one can return to the evolutionary theory that identifies the market failures that impede the innovation system from functioning properly (Arrow, 1962; Heijs, 2002). Specifically, companies may lack interest in investing in R\&D for several reasons (Heijs, 2002):

1. Uncertainty, connected with the asymmetry of information regarding aspects such as the developments of competitors, the unknown trends of future markets, and the possibility of unforeseen technical problems arising during the innovation process.

2. Externalities, related to the difficulty of fully capturing investment benefits, given that knowledge is easily reproduced and its use is not limited to those who produced it (appropriability problem).

3. Scale advantages, related to the lack of a linear relationship between technological efforts and the results achieved in the market.

The scientific literature demonstrates that companies benefitting from R\&D aid actually invest more in innovation (Bianchini; Llerena; Martino, 2019). In this scenario, the promotion of R\&D\&I dominates public administrations because of its strategic nature since innovation is one of the main forces driving growth and profitability (Tomás-Lopes; Marques-Serrasqueiro, 2017).

In Europe, the first steps towards a community scientific policy were made in 1974, with the first Framework Program introduced in 1982 (Fach-Gómez, 2014) that coordinated activities for the first time as part of a uniquely structured framework. Over the last 36 years, there have been eight research and innovation framework programs (1984-1987, 1987-1991, 19901994, 1994-1998, 1998-2002, 2002-2006, 2007-2013, and 2013-2020), in addition to the 2021-2027 program called Horizon Europe. Through these European programs, objectives are defined, and measures are adopted, together with bankable actions and temporal planning. In the program Horizon 2020 (H202O) a sharp difference among the member states

"with regard to the dissemination of the benefits derived from innovation" (Fach-Gómez, 2014, p. 16).

was demonstrated by the European Union. For this reason, $\mathrm{H} 2020$ had already included the aim of disseminating excellence, and 816.5 million euros was allocated for this purpose. With the same intention, the companies participating in this program were asked to design a communication plan that includes the communication, dissemination, and commercial exploitation of results, as well as to implement a system for measuring said results (Gertrudix et al., 2020). To facilitate the evaluation of these communication plans, the European Commission (2017) developed a Toolkit for the evaluation of the communication activities.

With Spain's entry into the EU, the approval of the Law for the promotion and general coordination of scientific and technical research (Law 13/1986) represented a shift in R\&D\&I policy (Pesquero-Franco; Muñoz-Alon-

The receipt of ERDF funds requires compliance with certain dissemination requirements so-López, 1997). From that moment on, Spain drafted a scientific and technological policy aimed at stimulating R\&D\&I in the business sector. In February 1988, the first National R\&D plan was approved, setting the following objectives:

- The programming and coordination of R\&D activities.

- The intensification of research efforts.

- The mobilization of private funds and stimulation of companies' capacity for innovation.

- The incorporation of new human resources into the science and technology system.

Public policies to support R\&D\&I in Spain came in a series of direct aid initiatives, such as non-refundable grants and/or subsidized credits, as well as indirect aid such as tax incentives (Busom; Martínez-Ros; Corchuelo, 2011). A relevant part of this aid is financed or co-financed by European funds. The European Union has made considerable efforts to promote innovation within companies, develop financial tools that support long-term regional growth (Varela-Vázquez; González-López; Sánchez-Carreira, 2019), and reduce inequalities between European regions (Moreno-Pires et al., 2019). Similarly, the European Regional Development Fund (ERDF) was created, aiming

"to strengthen economic and social cohesion in the European Union by correcting the imbalances between its regions" (European Commission, 2020).

The ERDF focuses its investments on several priority areas, one of which is innovation and research. Receiving ERDF funds also means accepting certain obligations, including the duty to publicize the aid received.

\subsubsection{Regulation of transparency and communication}

Progress has been made in both Spain and Europe to promote scientific, technological, and innovative dissemination and improve transparency. The Law of science, technology, and innovation (España, 2011) addresses the need to promote measures for

"scientific and technical research, innovation, knowledge transfer, dissemination, and scientific, technological, and innovative culture" (p. 35). 
In terms of transparency, progress has been made with the publication of the Law on transparency, access to public information and good governance (España, 2013), the creation of the Transparency portal of the Government of Spain, and the National database of grants. In this way, any citizen can find all the information pertaining to any aid granted. However, several experts have found deficiencies in compliance with the transparency law (Beltrán-Orenes; Martínez-Pastor, 2017; Cruz-Rubio, 2017).

In Spain, there is a regulatory framework that is complementary to the Transparency law (España, 2013) to address the communication requirements that must be applied by companies that receive direct R\&D\&l aid (España, 2003; Espa$\tilde{n} a, 2006 ; E U, 2013 ; E U, 2014)$. On the one hand, companies must comply with the requirements established in Royal decree 887/2006, which rules that beneficiaries must acknowledge the support of any funds and include their logos. On the other hand, companies must also comply with European Regulation No. 1303/2013, which came into force later and is mandatory, expanding the communication actions to be carried out, including the recognition of the support of any funds, a description of the project online, posters or a plaque in certain cases, and upon completion, a statement informing all parties, and a mention in the dissemination documents that are generated (Vilaplana-Aparicio; Martín-Llaguno; Iglesias-García, 2018).

To facilitate the communication tasks of companies and managing bodies, Regulation No. 1303 (EU, 2013) also includes technical specifications on emblems, logos, and posters and clarifies that the online description must include the purposes and results. However, it provides little detail on the depth of content required or the location of the information on the company's website. In this vein, Sanhueza, Rodríguez, and Padilla point to the need for clearly defined communication actions in the regulations since, as it is

"a costly process, lack of interest may arise to carry out these activities once the resources have already been received" (Sanhueza; Rodríguez; Padilla, 2012, p. 150).

Considering the effort that goes into innovation and its importance for the advancement of society, it is necessary to deploy effective innovation communication policies that contribute to transparent allocation of funds and greater dissemination without compromising the disclosure of key information that may interfere with its appropriability. For this reason, it is essential to explore expert opinion that will advance the definition of communication of innovation public policy.

\section{Objectives and methodology}

The purpose of this work is to assess the limitations and possibilities of improving the communication requirements (of dissemination and transparency) detailed in the obligations of companies receiving public R\&D\&I funds, specifically:

- the amount and type of information requested

- the formats and communication channels used

- the balance between confidentiality and dissemination

- the measures to be taken in the event of non-dissemination

- the support for the dissemination of the project's impact offered by the granting body

- the performance of the managing bodies in the evaluation of the communication plan

- the possible changes in legislation

- the possibility of collecting promotional actions as an eligible cost

- the incorporation of communication requirements in indirect aid

To meet these objectives, exploratory work was carried out to understand the state of this issue, rather than describing generalities through the extrapolation of data. For this purpose, we carried out semistructured interviews (Corbetta, 2007) with members of national and regional public agencies that manage R\&D\&I aid, expert organizations in business innovation and aid processing, managers of companies that receive this type of financing, and experts in communication, scientific dissemination, and transparency.

A total of 21 interviews were conducted during the period 2018-2020 (Table 1).

To select the experts, we used a combination of opinion sampling, which

"consists of selecting certain subjects as experts on the subject, because they maintain a certain perspective or experience in the field studied or because they are key informants" (Del-Rincón et al., 1995, pp. 324-325)

and snowball sampling (Corbetta, 2007). After the initial identification, we also incorporated contacts proposed by other interviewees because of their knowledge of R\&D\&I grant communication requirements. Firstly, three of the main Spanish R\&D\&I grant experts were identified and interviewed as they have extensive experience in national agencies managing R\&D\&I support tools (Carlos de la Cruz, Antonio Fernández, and Juan Manuel Garrido). In this initial selection, Javier Amorós, from the Subdirectorate General for Transparency and Good Governance, was also included.

All respondents were informed that the interview would be used for academic purposes and were subsequently asked to give their written consent to participate. To collect the information, face-to-face interviews were combined with telephone and written interviews, as well as video calls (Table 1), which all began with a structured script. Data processing was carried out by the elaboration of a protocol based on the defined issues. After data transcription, textual evidence relating to each issue was extracted, classified, synthesized, and examined. 
Table 1. Experts interviewed

\begin{tabular}{|c|c|c|c|c|}
\hline Area & & Person & Position & $\begin{array}{l}\text { Type of } \\
\text { interview }\end{array}$ \\
\hline \multirow{6}{*}{$\begin{array}{l}\text { National and } \\
\text { regional agencies }\end{array}$} & E1 & Carlos de la Cruz Molina & $\begin{array}{l}\text { Director of Technical Evaluation for the Center for the } \\
\text { Development of Industrial Technology (CDTI) }\end{array}$ & Face-to-face \\
\hline & E2 & Antonio Fernández Ecker & $\begin{array}{l}\text { Deputy Director General of Support to SMEs of the Minis- } \\
\text { try of Industry, Trade, and Tourism }\end{array}$ & Written \\
\hline & E3 & José María Peláez Bravo & $\begin{array}{l}\text { Deputy General for the Promotion of Innovation. Ministry } \\
\text { of Science, Innovation, and Universities }\end{array}$ & Written \\
\hline & E4 & Javier Mínguez Pontones & $\begin{array}{l}\text { Head of the Companies and Associations Area of the } \\
\text { Valencian Institute of Business Competitiveness (VAIBC) }\end{array}$ & Video call \\
\hline & E5 & Joaquín Gómez Gómez & $\begin{array}{l}\text { Director of the Murcia Development Institute and Presi- } \\
\text { dent of CEEIM, CEEIC, and Murcia Emprende }\end{array}$ & Written \\
\hline & E6 & Juan Manuel Garrido Moreno & $\begin{array}{l}\text { Director General of Innovation and Promotion of the } \\
\text { City of Madrid and former Deputy Director General of } \\
\text { Promotion of Business Innovation }\end{array}$ & $\begin{array}{l}\text { Face-to-face/ } \\
\text { telephone }\end{array}$ \\
\hline \multirow{2}{*}{$\begin{array}{l}\text { Experts in } \\
\text { transparency }\end{array}$} & E7 & Javier Amorós Dorda & $\begin{array}{l}\text { Subdirectorate General for Transparency and Good Gover- } \\
\text { nance }\end{array}$ & Face-to-face \\
\hline & E8 & Andrés Betancor Rodríguez & Professor of Administrative Law at Pompeu Fabra University & Written \\
\hline \multirow{7}{*}{$\begin{array}{l}\text { Experts in } \\
\text { innovation and } \\
\text { R\&D\&l aid }\end{array}$} & E9 & Jorge Barrero Fonticoba & General Director of the Cotec Foundation for Innovation & Face-to-face \\
\hline & E10 & Jesús Sanz Perpiñán & $\begin{array}{l}\text { Technical Deputy Director of the Technological Center of } \\
\text { Furniture and Wood of the Region of Murcia }\end{array}$ & Video call \\
\hline & E11 & Manuel Aragonés Francés & General Director of $A I J U$ & Written \\
\hline & E12 & Miguel Ángel Martínez Sánchez & $\begin{array}{l}\text { General Director of INESCOP, Center for Innovation and } \\
\text { Technology }\end{array}$ & Face-to-face \\
\hline & E13 & Carlos Hurtado Mengual & $\begin{array}{l}\text { Project Manager of the European Center for Business and } \\
\text { Innovation Cartagena (CEEIC) }\end{array}$ & Video call \\
\hline & E14 & Esther Peñalver Ibarra & $\begin{array}{l}\text { General Director of the European Center for Business and } \\
\text { Innovation of Murcia (CEEIM) }\end{array}$ & Written \\
\hline & E15 & Jesús Casanova Payá & $\begin{array}{l}\text { General Director of the European Center for Business and } \\
\text { Innovation Valencia (CEEI Valencia) }\end{array}$ & Written \\
\hline \multirow{3}{*}{$\begin{array}{l}\text { Experts in scientific } \\
\text { communication and } \\
\text { dissemination }\end{array}$} & E16 & María Jesús Pastor Llorca & $\begin{array}{l}\text { Vice-Rector for Transfer, Innovation and Scientific Disse- } \\
\text { mination of the Universidad de Alicante }\end{array}$ & Written \\
\hline & E17 & Elena Lázaro Real & $\begin{array}{l}\text { Coordinator of the UCCi at the University of Córdoba, pre- } \\
\text { sident of the Spanish Association for Scientific Communi- } \\
\text { cation and member of the permanent commission of the } \\
\text { Red Divulga de CRUE Universidades Españolas }\end{array}$ & Telephone \\
\hline & E18 & Marta María Fallola Sánchez-Herrera & $\begin{array}{l}\text { Head of the Scientific Culture Diffusion Service at the } \\
\text { Universidad de Extremadura }\end{array}$ & Written \\
\hline \multirow{3}{*}{ Business managers } & E19 & Juan García Legaz & Manager of Tecnimusa, SL & Written \\
\hline & E20 & Francisco Javier López Martínez & Manager of Alpred, SL & Written \\
\hline & E21 & Antonio Sánchez Zaplana & $\begin{array}{l}\text { Director of Innovation at Hidraqua, Gestión Integral de } \\
\text { Aguas de Levante, SA }\end{array}$ & Written \\
\hline
\end{tabular}

\section{Results}

4.1. Suitability of current measures: quantity and quality of information requested compared with quantity and quality of information that companies should provide

The experts agreed that the proposals include the requirements requested by Europe, but that they are dispersed and presented in different ways. The requested actions differ from one type of aid to another and among the organizations that grant them, indicating the need for homogenization (E16).

Although they consider the actions contemplated in the regulations to be sufficient, interviewees pointed to the progress that could be made (E4, E12, E15, E17, E18, E19). It is necessary to include the logos and project on the website, but one must also try to make the public aware of the funding results (E17), and the objective should not be only to inform citizens but to involve them (E18).

The specialists believe it is "correct to stimulate communication actions for R\&D\&I projects" (E11) since "it is a matter of getting the message across to citizens that their resources are 'good' for something" (E8).

To this end, they seek to ensure that the beneficiary "has a commitment to disseminate the project to society while it is being executed and once it is finished" (E4). 
However, although these publicity measures are important, in some cases, such as when subsidizing improvements to already established products, these requirements may be somewhat excessive (E20).
Citizens are unaware of the innovations that are being supported

Although company requirements are "increasingly exhaustive and require more and more dedication" (E13), the reality is that the public is unaware of the innovations supported, meaning current measures are insufficient (E9, E17). "We need entrepreneurial states that lead disruptions, and it is important to visualize public support when this occurs" (E9).

Along the same lines, E5, E10, and E17 point out that, if the purpose of communication is to convey actions to society, "with current measures this is not being achieved".

To comply with the Transparency law, organizations must publish the receipt of the grant, the granting body, the beneficiary, and the amount received. In this way, there are lists with the beneficiaries on their portals and, additionally, there is a National subsidy database that collects all the information over the lifespan of the subsidy (call, concession, beneficiary, amounts, etc.) (E7).

Regarding dissemination, the companies "advertise by incorporating the licenses/labels that inform that they have a funded project" and, during the follow-up, their compliance with the ERDF grant communication obligations is verified, as well as the publication of the data related to the financed project on their website (E1). In addition to what is required by law, the Centre for the Development of Industrial Technology (CDTI) also carries out communicative actions, such as the inclusion of successfully financed projects in its Perspectiva magazine and its collaboration "with TVE to make a series of videos" (E1), which are broadcast and available on YouTube.

The requirements are reasonable, but one of the main difficulties is that 'information is usually 'atomized,' making it difficult to access information in a centralized way" (E14).

For European projects, the measures are more well defined, and the most relevant aspects are addressed, training and guiding the companies that provide them with homogeneous and clear documentation (E19).In this regard, and in relation to the information that companies should provide, "the recipients of the aid must explain the added value provided by the project" (E14), as well as the social impact that is achieved with this investment (E17), and "what problems it has solved and what innovative solutions it proposes" (E18).

This could be possible through a written summary including the purposes and achieved impacts (E2, E4, E9, E12, E15, E17) or through information on the obtained results, such as the employment created (E2, E21) or investment produced (E2), from an informative approach without going into "relevant details that could put the protection of company knowledge at risk" (E16).

This latter aspect seems very important in the case of SMEs. An obligation to publish the results of an R\&D project may "conflict with private industrial interests" and act as "a disincentive for the company" (E19).

In fact, some companies consider that "information on the evolution and results of the project" should be limited (E20). Information must be provided that "shows that the public money received contributes to the progress of the country" (E8), and this must be "sufficiently detailed both to publicize the technological advances that are being developed, and to point out trends and new disruptive changes" (E13).

For this reason, the CDTI clarifies the need to know a project's impact, and $100 \%$ of the supported companied are surveyed. In addition, they indicate that, when a company presents a project's results at a conference or fair, they "should indicate that [they have] received public funding" (E1). Ultimately, "the citizen must know in which programs their taxes are spent, who receives these funds, and what impact these programs have on the state in order to make decisions in the future on whether to expand them, keep them as they are, or remove them" (E1).

These measures do not only benefit citizens; developing a comprehensive communication plan with certain objectives and a defined target audience increases the prominence and social recognition of both the research and the company (E18).

Apart from focusing the information to respond to the questions set out, the experts also discussed the formats and language used, suggesting that they should be reviewed (E9). The information should be structured well, and a preestablished script should be developed to systematize the process (E4, E11).

The optimal time to provide information could be at the end of the project, which would be advantageous to the receiving entity making the effort (E9, E10), which must be given the opportunity to register patents, utility models, or other registration models (E12, E15). 


\subsection{Formats and communication channels}

The appropriateness of the communication "is not verified; it is verified that it has been done, and that's it" (E7).

Experts point to the weakness of the required formats and channels. "The broadcaster would have to make an effort to use the channels and the media that people use now, with more modern formats. We should start working on short videos, infographics, videogames, etc." since we need younger audiences to receive the message and "feel part of the innovation ecosystem" (E9). Digital communication is changing at a dizzying rate; therefore, "scientific dissemination must go hand in hand with new trends" (E16).

In addition, with the possibilities offered by the internet (E8, E12, E18, E19), social networks (E2, E4, E11, E15, E16, E18, E19, E21), and multichannel broadcasting (E11, E17), more work should be done to utilize these platforms. Social networks are especially interesting because they allow segmentation of audiences (for example, Instagram for young people), and among the various options, Twitter is considered to be the best social network for scientific dissemination to the general public (E18), or ResearchGate or Academia for more specialized scientific audiences (E16).

Although digital communication offers wide possibilities and advantages, "it is undeniable that communication in public spaces in direct contact with the public achieves very significant interactions" that should be valuable, such as "scientific cafes, talks, debates, gatherings" (E18).

It would be useful to carry out public events with a didactic approach where the project results are presented "for all audiences" (E21).

The format used in El Exportador from ICEX is interesting. Broadcast on TVE2, a platform accessible from the ICEX portal and YouTube, it has presented several success stories (E10). Similarly, in addition to producing the Perspectiva magazine, $C D T I$ has opted for the dissemination of videos, the publication of news in the economic and specialized press, and the dissemination of events through social networks (E1).

However, the use of some channels and the determination of the information to be transmitted should depend "on the type of project and the target audience that one wants to reach" (E5). Furthermore, "the key is not only in the formats and media used, but also in how one measures the impact of the communication actions" (E17).

The response to such dissemination should be presented since "it is useless to publish a paper if it is not quoted or read" (E21). On the other hand, it would also be necessary to create a digital repository for public consultation that would combine all the information in one place, thereby avoiding dispersion (E13, E14).

\subsection{The balance between confidentiality and dissemination: measures to be taken in the event of non-dis- semination}

According to expert opinion, setting the boundaries between communication obligations and confidentiality is complex. Although there is almost total consensus that project information should be provided without compromising confidentiality (E4, E11, E12, E14, E16, E20, E21), others think that "there can be no confidentiality when it comes to public money. The beneficiary of this money cannot hide any secrets. It is the tradeoff for the benefit" (E8).

However, "companies can reveal many things without releasing privileged information" (E9) since they can explain their start and end points without revealing their plan of action (E12). In general, citizens do not need to understand the developed technology in depth, only how it benefits them (E17) since the "processes behind an R\&D\&I project are complex and difficult to understand for the vast majority of society" (E20).

In the process of project dissemination, the protection of results is a more sensitive issue since the survival of the company may depend on it; therefore, "you have to be very careful with the sensitive information that can be disseminated" (E1).

Aid is granted to make the company "more competitive in its market"; similarly, "the form and content of the disclosure must be correctly assessed to avoid giving clues to the competition" and violating "the requirement of novelty" that could hinder the application for a patent or utility model (E16).

If receiving the aid forces you to disclose information that reduces your advantage over the competition, "the aid loses the meaning it was seeking" (E10).

There "should be no conflict with the obligation to publicize results" if there is a "prior, clear, and homogeneous definition of the data to be provided" that will allow the company to understand the scope of the information required and enable the implementation of innovation protection measures from the early stages (E19).

Defining these limits could be the responsibility of the Ministry of Science, Innovation, and Universities. Likewise, "the limits should operate on a case-by-case basis, that is, they should be differentiated in some way because not all projects require the same level of confidentiality"and, in cases where there is a limitation, this should be demonstrated (E7). In addition, it could be differentiated according to the size of the aid or the sector to which the company belongs, with the ability to be more lenient with smaller projects or sectors that require greater confidentiality (E10). Furthermore, the 
regulations governing the aid should provide sanctions if any of the parties involved in the process break the project's confidentiality (E2).

In this sense, all the interviewees agree that communication measures must be complied with. The non-dissemination penalty, after a penalty-free first warning, could be linked to a percentage of the funding (E5, E15, E16, E18, E19) or result in total or partial revocation of the aid, depending on the commitments taken on (E4, E8, E12, E13, E14); however, this would require this possibility "to be included in the aid regulations" (E2).

Another penalty possibility could be to publish the names of the companies that do not comply, given that this has been effective for similar cases (E7), or disallowing participation in subsequent R\&D\&l calls for tenders (E21).

Conversely, instead of focusing on penalties, a recognition of the efforts made could be effective (E7, E11). To do this, a "transparency seal could be created that rewards, in some way, compliance with communication measures and carrying out additional activities" (E7).

\subsection{Support for dissemination of the impact of the project offered by the granting body}

Organizations such as the CDTI and their magazine Perspectiva carry out dissemination actions or participate in the organization of dissemination days that include beneficiary companies' experiences (E1). Consequently, aware of the importance of communication, the CDTI claims to be: “...working on good practices, including enabling a web portal for dissemination, recommendations for the preparation of press releases, presentations about the project, and videos. Companies will also be helped to present their projects in the media (press, radio, and TV) and on social networks" (E1).

However, while some experts consider the current actions sufficient (E20), most of them agree that managing bodies should be carrying out more dissemination actions. Several interviewees (E9, E10) stated that practically all communication responsibilities should fall on the managing body since it has greater capacity for communication and negotiation with the media. Some of the actions they suggest are as follows:

- Communicate informative programs in the media, such as radio or TV (E10, E17).

- Establish interventions in educational centers to explain what is being done (E10).

- Collate the information on a single website (E10, E13, E14, E19). The site could be the Transparency portal, but it could be made more intuitive and more informative (E10).

- Accompany and help companies to carry out communication or facilitate their efforts (E4, E7, E11, E13, E17).

- Carry out communication campaigns with the inclusion of success stories (E7).

- Organize dissemination sessions (E2).

- Take actions through social networks (E2).

- Publish press releases or articles in specialized magazines (E2).

- Involve journalists specialized in popular science (E14).

- Report news in the media of the results obtained in each call for tenders, their implications, and future projections (E15).

The organizations' specialized communication services could be used to help SMEs define their own communication strategies, this is "where the improvement would be, if we achieve that the minimum requested communication is formulated with more informative criteria" (E17).

These internal resources or communication agencies of the managing bodies "could help create style guides and dissemination standards for the projects' publicity actions" (E21).

There is full consensus about the capacity of managing bodies to assess communication actions and their quality. Our experts consider the need to define the evaluation criteria and the evidence that will be presented. Some point to the requirement of providing these organizations with more means to carry out these actions (E5, E14, E4) and incorporating communication specialists who could transform technical information into language that is more accessible to citizens (E10). However, in any case, "the evaluation of communication plans must be done by communication professionals" (E17) and must "present impact indicators that are specific, measurable, quantifiable, realistic, and based on a certain time" (E18).

\subsection{Possible changes in legislation}

Some of the interviewees do not think that any regulatory framework changes are needed. Instead, they consider Spain to have "good laws" (E7), and that the focus should be on compliance (E7, E11) or dissemination of these (E21). Given that, in recent years, substantial progress has been made in dissemination, particularly through social media, "it would be premature to make legislative changes before verifying that current legislation is being fully complied with and that it is satisfactory" (E1).

Instead of making a legislative change, "a change could be made in the instructions, in the basic rules of the aid, or in the internal processes of the managing body" (E9).

By contrast, other interviewees consider that "greater clarity would be necessary" (E19) and that "there should be an adaptation to new trends and a homogenization with the legal texts at the European level" (E16). 
In addition, "the impact, in terms of communication, is insufficient" and "the global importance that communication has in the R\&D\&l ecosystem" should be highlighted in each call for tenders (E5), along with the requirements themselves (E18). These calls for research programs could also "positively evaluate projects that present comprehensive communication plans" (E18).

Furthermore, "the legislation, in general, only considers the grants", while it should be changed to "increase the weight and importance of the evaluation of the results" (E8). It is also essential to "promote simplicity" (E15) and "standardize and combine the different existing laws" through the use of a "language closer to the business-owner" (E13) so that communication requirements are reflected in all calls in the same way (E12, E14), and "facilitating the process for companies that are also not so familiar with the legislation" (E12).

\subsection{The possibility of including promotional actions as an eligible cost}

If the "communication of R\&D\&I is one more process within the R\&D\&I ecosystem", we must support dissemination actions (E5) because they will result in more effective communication (E17). Is it crucial for SMEs to consider communication as an important part of the project (E16). In European funding (H2020, Interreg, COSME, LIFE, etc.), dissemination expenses are considered eligible to ensure correct dissemination (E14, E21).

The fact that project dissemination actions are not considered to be an eligible cost $(E 1, E 8)$ is a pending issue. One of the main limitations is that the "Community State Aid Framework does not include it as a differentiated cost, nor does it assign a specific aid intensity" (E1).

There are several proposals to raise financial support: set a fixed amount for this type of action or a percentage of the aid (E2, E21), "establish a medium-long-term strategy where the eligible percentage decreases over time" (E5), or provide "instrumental support" for companies (E7).

There are some more interesting communication actions to support, such as communication through social networks (E18, E19), as these are high impact and very versatile. However, "updating and publishing attractive, relevant, and sociaIly interesting content on social networks and their monitoring/evaluation require time and resources" (E18), and some experts think the beneficiary (E4, E20) should assume this role since the priority of the funds is to support "activities with technological risk" (E4).

\subsection{Communication in indirect aid}

The aspect generating the most controversy is the communication associated with tax incentives, among other measures, because "they are usually applied after the closure and justification of the project" (E16).

On the one hand, the interviewees agree that companies taking advantage of these incentives should comply with minimum communication actions (E1, E11, E13, E14, E15, E21) to improve transparency and attract small companies that may be apprehensive and distrusting (E12, E14, E19), as long as no reductions in other aid are implied since resources are limited (E17). On the other hand, for SMEs themselves, adequate dissemination of the aid received, be it direct or indirect, "contributes to the recognition of the innovative work of the SME and its leadership in R\&D" (E19).

Public organizations are becoming more aware of the importance of increasing visibility, "which could be implemented from the very public administrations that have encouraged the project, by supporting the company so that it does it as it deems best, or some other formula" (E3).

However, this is a question that deserves more attention: "For consistency with the transparency policy, and since they are also public incentives, it would seem logical that, with the tax deductions for R\&D\&I and the patent box, at least the same information that is presented for other R\&D incentives should be made public. However, this would represent a regulatory change, since tax returns are confidential, and deductions are a part of them" (E3).

Some interviewees point out that companies could be asked for some direct communicative action. This is happening de facto with the entities that achieve the Innovative SME Certification and make it visible. A first step would be to carefully "analyze the cost/benefit of taking this measure" since its incorporation could "drain resources that are very limited". Likewise, "including dissemination expenses in the deductions would be complex because it would mean revising the corporation tax law", together with the legislation that regulates the issuing of reasoned reports. To date, "financing communication is not possible, and I am not totally convinced whether it would be appropriate because it is not the purpose of what is being supported, which are R\&D\&I projects". The aid seeks "to share the risk of an uncertain development, and the dissemination itself does not have that element of risk" (E6).

On the other hand, several interviewees agree that tax matters are sensitive and reserved, and this question would require deep reflection $(E 2, E 7)$ since "this information channel is more delicate than that of a subsidy and requires an extensive legal analysis" (E6).

However, although promotion of this should be a company decision (E20), there are intermediate steps, such as providing data aggregated by sector (E7, E10). 


\section{Discussion and conclusions}

This work confirms the value of communication, in line with what has been proposed by the current innovation dissemination trends and works studying the value of transparency (Wijnhoven; Ehrenhard; Kuhn, 2015; Brown; Martinsson, 2017).

However, in line with Pedreño-Muñoz and Moreno-Izquierdo (2020), who affirm that the social impact of innovation dissemination has not been measured or valued (one of the failures of public policies supporting innovation), our work highlights the various possibilities for improvement in the communication requirements of the companies receiving aid from public institutions.

The communication actions required by companies that receive R\&D\&I funds comply with the requirements established by law, but according to the interviewees, they are insufficient. This confirms what has been stated by the European Union itself when it expressed the deficiencies in the benefits of innovation dissemination (Fach-Gómez, 2014) and ratifies contributions by Pacios, Vianello-Osti, and Rodríguez-Bravo (2016), who observe a similar phenomenon in university research projects. In agreement with Mea et al. (2016), this study concurs that the communication actions required are minimal and in somewhat obsolete formats and channels. This could lead to a low communication impact, something that should be addressed in future work.

Companies must be obliged to provide information on the impact achieved by their innovations. Communication must be incorporated into this requirement, an aspect previously indicated by Gertrudix et al. (2020) and that has only been studied in European projects (Mea et al., 2016; Gertrudix et al., 2020) where communication is subsidized.

Neither the formats, means, nor the effectiveness of the innovation dissemination are being tested. There is a need to broaden perspectives and modernize communication instruments. The interviewees encourage the exploration of other communication formulas, in line with what Burmester et al. (2015) suggested when speaking of the effectiveness of publicity. With the continuous evolution of media and their various formats, the most appropriate proposal at this time seems to be to define some updated guidelines and ask companies to present and justify their communication plans before they begin developing their projects. To this end, it would be very useful to define criteria for the evaluation of communication activities, as exemplified by the European Union itself (European Commission, 2017).

The role of managing bodies seems fundamental to promoting improvements in both dissemination and transparency. We can highlight the actions carried out by the CDTI (using social networks or short videos to publish success stories), but experts point out that the activity of these entities could still be improved. A new line of research is opened with novel studies comparing similar institutions in other countries and the objective measurement of the effects of these actions. We cannot forget that investment in advertising and innovation directly impacts the economic growth of a country (Cavenaile; Roldan, 2019).

Regarding the limits between communication requirements and confidentiality, our results suggest the need to delve deeper into this issue to elucidate what information a company should provide without having to compromise its developments. These results are consistent with the works of Brown and Martinsson (2017) and Bloom, Van Reenen, and Williams (2019) that highlight how providing excess information could have a dissuasive effect on companies. The interviewees consider that beneficiary companies could provide more information without compromising projects or hindering their appropriability, as indicated by Heijs (2002).

Managing bodies are responsible for monitoring company compliance with communication measures. In line with what has been pointed out by other authors (Beltrán-Orenes; Martinez-Pastor, 2017; Cruz-Rubio, 2017), our work indicates that procedures must be improved since there are deficiencies in company compliance. Although noncompliance with dissemination measures is contemplated in the regulatory texts, they are scattered and nonspecific. In addition to detailing these regulatory measures, it is also necessary to determine penalty options and assess the possibility of rewarding entities that are excellent at communication, as demonstrated in other settings (Chelala; Giarrizzo, 2014).

One of the conclusions of this work focuses on the lack of consensus on how to pay for communication actions. Experts agree on providing support to communicative actions, albeit with different criteria. This is consistent with the line of enquiry followed by the European Union itself, which expressed the need to improve the communication process of R\&D\&I projects (Fach-Gómez, 2014) and included communication as an eligible item. By asking companies to design a communication plan including the actions and systems for measuring results, they are encouraged to reflect on and analyze which dissemination actions are the most appropriate for their audience, as concluded by Gertrudix et al. (2020). In this way, as it is a supportable cost, it requires mandatory supervision and assessment by the granting body. Although experts do not consider it necessary to make legislative changes, it seems relevant to standardize the actions contemplated in both Spain (Spain, 2003; Spain, 2006) and the European Union (EU, 2013) regulations and the different R\&D\&I calls for tender.

Communication associated with indirect aids seems to be the most complex issue to solve. The results demonstrate the need to advance in this regard to align with direct aid. The incorporation of some communication me-
According to the EU, there are deficiencies in the dissemination of innovation projects 
asures could be studied and reflected on when carrying out communicative actions. A first step towards transparency could include the publication of aggregated data, which will reveal the scope of this aid.

Future lines of research could focus on studying whether the communication strategy of companies varies depending on the different stages of the innovation process, as pointed out by Ye, Jha, and Desouza (2015), and elucidating whether the size of the company is decisive when preparing a company's communication plan, as argued by Xu, Liu, and Chen (2019). It would also be useful to study the communication policies followed by other European countries.

\section{Note}

1. Source: Eurostat. Gross Domestic Expenditure on RD:

https://bit.ly/3ol2fyG

\section{References}

Arrow, Kenneth J. (1962). "The economic implications of learning by doing". Review of economic studies, v. 29, n. 2, pp. 155-173.

https://doi.org/10.2307/2295952

Bahrami, Soheila; Atkin, Brian; Landin, Anne (2019). "Innovation diffusion through standardization: A study of building ventilation products". Journal of engineering and technology management, v. 54, pp. 56-66.

https://doi.org/10.1016/j.jengtecman.2019.11.001

Baptista, Rui (1999). "The diffusion of process innovations: A selective review". International journal of the economics of business, v. 6, n. 1, pp. 107-129.

https://doi.org/10.1080/13571519984359

Bass, Frank M. (1969). “A new product growth for model consumer durables”. Management science, v. 15, n. 5, pp. $215-227$. https://doi.org/10.1287/mnsc.1040.0264

Bass, Frank M.; Krishnan, Trichy V.; Jain, Dipak C. (1994). "Why the Bass model fits without decision variables". Marketing science, v. 13, n. 3, pp. 203-223.

https://doi.org/10.1287/mksc.13.3.203

Baysinger, Barry D.; Kosnik, Rita D.; Turk, Thomas A. (1991). "Effects of board and ownership structure on corporate RD strategy". The Academy of Management journal, v. 34, n. 1, pp. 205-214.

https://doi.org/10.5465/256308

Beltrán-Orenes, Pilar; Martínez-Pastor, Esther (2017). “Organization of the information and obligated subjects in the Portal de la Transparency of Spain”. El profesional de la información, v. 26, n. 5, pp. 983-994.

https://doi.org/10.3145/epi.2017.sep.19

Bianchini, Stefano; Llerena, Patrick; Martino, Roberto (2019). "The impact of RD subsidies under different institutional frameworks". Structural change and economic dynamics, v. 50, pp. 65-78.

https://doi.org/10.1016/j.strueco.2019.04.002

Bloom, Nicholas; Van-Reenen, John; Williams, Heidi (2019). "A toolkit of policies to promote innovation". Journal of economic perspectives, v. 33, n. 3, pp. 163-84.

https://doi.org/10.1257/jep.33.3.163

Brown, James R.; Martinsson, Gustav (2017). "Does transparency stifle or facilitate innovation?". Swedish House of Finance research paper, n. 15-16.

https://doi.org/10.2139/ssrn.2498250

Burmester, Alexa B.; Becker, Jan U.; Van-Heerde, Harald J.; Clement, Michel (2015). "The impact of pre-and post-launch publicity and advertising on new product sales". International journal of research in marketing, v. 32, n. 4, pp. 408-417. https://doi.org/10.1016/j.ijresmar.2015.05.005

Busom, Isabel; Martínez-Ros, Ester; Corchuelo, Beatriz (2011). “Obstáculos a la innovación y uso de incentivos: ¿Subvenciones o estímulos fiscales?”. Economía industrial, n. 386, pp. 35-44.

https://cutt.ly/fnqYW5I

Casadesús-de-Mingo, Anahí; Cerrillo-Martínez, Agustí (2018). “Improving records management to promote transparency and prevent corruption". International journal of information management, v. 38, n. 1, pp. 256-261.

https://doi.org/10.1016/j.ijinfomgt.2017.09.005

Cavenaile, Laurent; Roldán, Pau (2019). Advertising, innovation and economic growth.

https://repositorio.bde.es/bitstream/123456789/8816/1/dt1902e.pdf 
Chaudhary, Kuldeep; Jha, Prakash C. (2018). Optimal control promotional policy for a new product incorporating repeat purchase in segmented market: A control theoretic approach. In: Industrial engineering. IntechOpen. https://doi.org/10.5772/intechopen.81385

Chelala, Santiago; Giarrizzo, Victoria (2014). “Evasión de impuestos en Argentina: Un análisis experimental de la eficiencia de premios y castigos al contribuyente". Revista finanzas y política económica, v. 6, n. 2, pp. 269-286. http://www.scielo.org.co/scielo.php?pid=S2248-60462014000200003\&script=sci_abstract\&tlng=es

Cini, Michelle (2008). "European Commission reform and the origins of the European Transparency Initiative". Journal of European public policy, v. 15, n. 5, pp. 743-760.

https://doi.org/10.1080/13501760802133245

Comision Europea (2017). Toolkit for the evaluation of the communication activities. https://ec.europa.eu/info/sites/info/files/communication-evaluation-toolkit_en.pdf

Comisión Europea (2020). European Regional Development Fund. https://ec.europa.eu/regional_policy/en/funding/erdf

Corbetta, Piergiorgio (2007): Metodología y técnicas de investigación social. Madrid: McGraw Hill. ISBN: 9788448156107

Cruz-Rubio, César-Nicandro (2017): Ley de transparencia y grandes empresas en España. Madrid: Transparency International España. ISBN: 9788469743089

Cucciniello, Maria; Porumbescu, Gregory A.; Grimmelikhuijsen, Stephan (2017). "25 years of transparency research: Evidence and future directions". Public administration review, v. 77, n. 1, pp. 32-44.

https://doi.org/10.1111/puar.12685

Del-Rincón, Delio; Arnal, Justo Agustín; Latorre-Beltrán, Antonio; Sans-Martín, Antonio (1995). Técnicas de investigación en ciencias sociales. Madrid: Dykinson. ISBN: 848155 104X

Dhakal, Thakur; Min, Kyong-Soon; Lim, Dae-Eun (2019). "Review of multi-generation innovation diffusion models". Industrial engineering \& management systems, v. 18, n. 4, pp. 794-807.

https://doi.org/10.7232/iems.2019.18.4.794

Dockner, Engelbert; Jørgensen, Steffen (1988). “Optimal advertising policies for diffusion models of new product innovation in monopolistic situations". Management science, v. 34, n. 1, pp. 119-130.

https://doi.org/10.1287/mnsc.34.1.119

Dodson, Joe A.; Muller, Eitan (1978). "Models of new product diffusion through advertising and word-of-mouth". Management science, v. 24, n. 15, pp. 1568-1578.

https://doi.org/10.1287/mnsc.24.15.1568

Egyedi, Tineke M.; Ortt, J. Roland (2017). Towards a functional classification of standards for innovation research. In: R. Hawkins, K. Blind and R. Page (eds.), Handbook of innovation and standards. Cheltenham, United Kingdom: Edward Elgar, pp. 105-131.

https://doi.org/10.4337/9781783470082

Ekblom, Aura-Camelia (2018). Facebook groups for dissemination of EU-funded Projects. An exploratory study of knowledge sharing in communities of interest in social media.

España (2003). “Ley 38/2003, de 17 de noviembre, general de subvenciones”. BOE, n. 276, 18 noviembre. https://www.boe.es/buscar/act.php?id=BOE-A-2003-20977

España (2006). “Real decreto 887/2006, de 21 de julio, por el que se aprueba el Reglamento de la Ley 38/2003, de 17 de noviembre, General de subvenciones". BOE, n. 176, 25 julio.

https://www.boe.es/diario_boe/txt.php?id=BOE-A-2006-13371

España (2011). “Ley 14/2011, de 1 de junio, de la Ciencia, la Tecnología y la Innovación". BOE, n. 131, 2 junio. https://www.boe.es/buscar/act.php?id=BOE-A-2011-9617

España (2013). "Ley 19/2013, de 9 de diciembre, de transparencia, acceso a la información pública y buen gobierno". $B O E$, n. 295, 10 diciembre.

https://www.boe.es/buscar/doc.php?id=BOE-A-2013-12887

Fach-Gómez, Katia (2014). "The new EU policy on research and innovation: Horizon 2020 and the role of social sciences \& humanities". Revista general de derecho europeo, n. 33.

https://www.iustel.com/v2/revistas/detalle_revista.asp?id_noticia $=414767 \& d=1$

Fan, Zhi-Ping; Che, Yu-Jie; Chen, Zen-Yu (2017). "Product sales forecasting using online reviews and historical sales data: A method combining the Bass model and sentiment analysis". Journal of business research, v. 74, pp. 90-100.

https://doi.org/10.1016/j.jbusres.2017.01.010 
Geiger, Christian-Philipp; Von-Lucke, Jörn (2012). “Open government and (linked) (open) (government) (data)". eJournal of edemocracy and open government, v. 4, n. 2, pp. 265-278.

https://doi.org/10.29379/jedem.v4i2.143

Gertrudix, Manuel; Rajas, Mario; Gertrudis-Casado, María-del-Carmen; Gálvez-de-la-Cuesta, María-del-Carmen (2020). "Gestión de la comunicación científica de los proyectos de investigación en H2020. Funciones, modelos y estrategias". Profesional de la información, v. 29, n. 4, e290424.

https://doi.org/10.3145/epi.2020.jul.24

Grimmelikhuijsen, Stephan; Herkes, Feie; Leistikow, Ian; Verkroost, Jos; De-Vries, Femke; Zijlstra, Wilte G. (2019). “Can decision transparency increase citizen trust in regulatory agencies? Evidence from a representative survey experiment". Regulation \& governance. https://doi.org/10.1111/rego.12278

Grimmelikhuijsen, Stephan; Porumbescu, Gregory; Hong, Boram; Im, Tobin (2013). "The effect of transparency on trust in government: A cross-national comparative experiment". Public administration review, v. 73, n. 4, pp. 575-586. https://doi.org/10.1111/puar.12047

Grimmelikhuijsen, Stephan G.; Welch, Eric W. (2012). "Developing and testing a theoretical framework for computer-mediated transparency of local governments". Public administration review, v. 72, n. 4, pp. 562-571. https://doi.org/10.1111/j.1540-6210.2011.02532.x

Gruenhagen, Jan-Henrik; Parker, Rachel (2020). "Factors driving or impeding the diffusion and adoption of innovation in mining: A systematic review of the literature". Resources policy, v. 65 (C).

https://doi.org/10.1016/j.resourpol.2019.101540

Hall, Bronwyn H. (2002). "The financing of research and development". Oxford review of economic policy, v. 18, n. 1, pp. 35-51.

https://doi.org/10.1093/oxrep/18.1.35

Heald, David (2006). "Varieties of transparency". In: Hood, Christopher; Heald, David (eds.), Transparency: The key to better governance?. Oxford, UK: Oxford University Press, pp. 25-43. ISBN: 9780197263839

Heckmann, Dirk (2011). "Open government-Retooling democracy for the $21^{\text {st }}$ century". In: 44th Hawaii international conference on system sciences.

https://doi.org/10.1109/HICSS.2011.334

Heijs, Joost (2002). “Justificación de la política tecnológica: Un enfoque teórico”. Revista Madrid I+D, v. 10. https://www.madrimasd.org/revista/revista10/aula/aulas2.asp

Horsky, Dan; Simon, Leonard S. (1983). “Advertising and the diffusion of new products”. Marketing science, v. 2, n. 1, pp. 1-17. https://doi.org/10.1287/mksc.2.1.1

Horvat, Andrijana; Fogliano, Vicenzo; Luning, Pieternel A. (2020). "Modifying the Bass diffusion model to study adoption of radical new foods - The case of edible insects in the Netherlands". Plos one, v. 15, n. 6.

https://doi.org/10.1371/journal.pone.0234538

Iturrate-Meras, Diana (2019). "Ambivalence towards innovation: the social perception of risks and benefits associated with innovation in Spanish society". Revista española de sociología, v. 28, pp. 93-114.

https://doi.org/10.22325/fes/res.2019.30

Kaiser, Ulrich (2005). "A microeconometric note on product innovation and product innovation advertising". Economics of innovation and new technology, v. 14, n. 7, pp. 573-582.

https://doi.org/10.1080/1043859042000269115

Kalish, Shlomo (1985). "A new product adoption model with price, advertising and uncertainty". Management science, v. 31, n. 12, pp. 1569-1585.

https://doi.org/10.1287/mnsc.31.12.1569

Leibowicz, Benjamin D. (2018). “Welfare improvement windows for innovation policy”. Research policy, v. 47, n. 2, pp. 390-398.

https://doi.org/10.1016/j.respol.2017.12.009

Mahajan, Vijay; Muller, Eitan; Bass, Frank M. (1990). "New product diffusion models: A review and directions for research". Journal of marketing, v. 54, n. 1, pp. 1-26.

https://doi.org/10.2307/1252170

Martin, Stephen; Scott, John T. (2000). "The nature of innovation market failure and the design of public support for private innovation". Research policy, v. 29, n. 4-5, pp. 437-447.

https://doi.org/10.1016/S0048-7333(99)00084-0 
Mea, Marianna; Newton, Alice; Uyarra, María C.; Alonso, Carolina; Borja, Ángel (2016). "From science to policy and society: Enhancing the effectiveness of communication". Frontiers in marine science, v. 3. https://doi.org/10.3389/fmars.2016.00168

Meade, Nigel; Islam, Towhidul (2006). "Modelling and forecasting the diffusion of innovation - A 25-year review". International journal of forecasting, v. 22, n. 3, pp. 519-545. https://doi.org/10.1016/j.ijforecast.2006.01.005

Mehta, Sunita; Chaudhary, Kuldeep; Kumar, Vijay (2020). "Optimal promotional effort policy in innovation diffusion model incorporating dynamic market size in segment specific market". International journal of mathematical, engineering and management sciences, v. 5, n. 4, pp. 682-696. https://doi.org/10.33889/IJMEMS.2020.5.4.055

Mesak, Hani I.; Clark, James W. (1998). "Monopolist optimum pricing and advertising policies for diffusion models of new product innovations". Optimal control applications and methods, v. 19, n. 2, pp. 111-136.

https://doi.org/10.1002/(SICI)1099-1514(199803/04)19:2\%3C111::AID-OCA622\%3E3.0.CO;2-M

Monahan, George E. (1984). "A pure birth model of optimal advertising with word-of-mouth". Marketing science, v. 3, n. 2, pp. 169-178.

https://doi.org/10.1287/mksc.3.2.169

Moreno-Pires, Sara; Polido, Alexandra; Teles, Filipe; Silva, Pedro; Rodrigues, Carlos (2019). "Territorial innovation models in less developed regions in Europe: the quest for a new research agenda?". European planning studies, v. 28, n. 8, pp. 1639-1666. https://doi.org/10.1080/09654313.2019.1697211

Pacios, Ana-Reyes; Vianello-Osti, Marina; Rodríguez-Bravo, Blanca (2016). "Transparency and access to information on research projects in Spanish public universities”. El profesional de la información, v. 25, n. 5, pp. 721-729. https://doi.org/10.3145/epi.2016.sep.02

Pedreño-Muñoz, Andrés; Moreno-Izquierdo, Luís (2020). Europa frente a EE.UU. y China. Prevenir el declive en la era de la inteligencia artificial. ISBN: 9788409212118

Peres, Renana; Muller, Eitan; Mahajan, Vijay (2010). "Innovation diffusion and new product growth models: A critical review and research directions". International journal of research in marketing, v. 27, n. 2, pp. 91-106.

https://doi.org/10.1016/j.ijresmar.2009.12.012

Pesquero-Franco, Encarna; Muñoz-Alonso-López, Gemma (1997). “Consideraciones teóricas y evolución del Plan Nacional de la Investigación Científica y el Desarrollo Tecnológico". Revista general de información y documentación, v. 7, n. 1, pp. 169-185.

https://revistas.ucm.es/index.php/RGID/article/download/RGID9797120169A/11019

Piotrowski, Suzanne J.; Van-Ryzin, Gregg G. (2007). "Citizen attitudes toward transparency in local government". The American review of public administration, v. 37, n. 3, pp. 306-323.

https://doi.org/10.1177/0275074006296777

Ratcliff, Ryan; Doshi, Kokila (2016). "Using the bass model to analyze the diffusion of innovations at the base of the pyramid". Business \& society, v. 55, pp. 271-298.

https://doi.org/10.1177/0007650313479529

Rogers, Everett M. (1962). Diffusion of innovations. New York: Free Press of Glencoe. ISBN: 0612628434

Sanhueza, Paulina; Rodríguez, Ignacio; Padilla, Patricio (2012). "Diffusion and access to scientific and technological data in the regulatory framework of innovation public funds in Chile". Journal of technology management \& innovation, v. 7, n. 4, pp. 148-163.

https://doi.org/10.4067/S0718-27242012000400012

Simon, Hermann; Sebastian, Karl-Heinz (1987). "Diffusion and advertising: The German telephone campaign". Management science, v. 33, n. 4, pp. 451-466.

https://doi.org/10.1287/mnsc.33.4.451

Tanny, Stephen M.; Derzko, Nicholas A. (1988). "Innovators and imitators in innovation diffusion modelling". Journal of forecasting, v. 7, n. 4, pp. 225-234. https://doi.org/10.1002/for.3980070403

Tomás-Lopes, Ilídio; Marques-Serrasqueiro, Rogério (2017). "The influence of culture and transparency on global research and development intensity: An overview across Europe". Contaduría y administración, v. 62, n. 4, pp. $1408-1422$. https://doi.org/10.1016/j.cya.2017.06.002 
Turk, Tomaž; Trkman, Peter (2012). "Bass model estimates for broadband diffusion in European countries". Technological forecasting and social change, v. 79, n. 1, pp. 85-96.

https://doi.org/10.1016/j.techfore.2011.06.010

UE (Unión Europea) (2013). "Regulation No 1303/2013 of the European Parliament and of the Council of 17 December 2013 laying down common provisions for the European Regional Development Fund, the European Social Fund, the Cohesion Fund, the European Agricultural Fund for Rural Development and the European Marine and Fisheries Fund, and laying down general provisions concerning the European Regional Development Fund, the European Social Fund, the Cohesion Fund and the European Marine and Fisheries Fund, and repealing the Regulation (EC) no. 1083/2006 of the Council". Official Journal of the European Union.

https://eur-lex.europa.eu/legal-content/EN/TXT/?uri=celex:32013R1303

UE (Unión Europea) (2014). "Regulation No 821/2014 of 28 July 2014 laying down rules for the application of Regulation (EU) No 1303/2013 of the European Parliament and of the Council as regards detailed arrangements for the transfer and management of programme contributions, the reporting on financial instruments, technical characteristics of information and communication measures for operations and the system to record and store data". Official Journal of the European Union.

https://eur-lex.europa.eu/legal-content/EN/TXT/?uri=uriserv:OJ.L_.2014.223.01.0007.01.ENG

Varela-Vázquez, Pedro; González-López, Manuel; Sánchez-Carreira, Maria-del-Carmen (2019). “The uneven regional distribution of projects funded by the EU Framework Programmes". Journal of entrepreneurship, management and innovation, v. 15, n. 3, pp. 45-72.

https://doi.org/10.7341/20191532

Vilaplana-Aparicio, María J.; Martín-Llaguno, Marta; Iglesias-García, Mar (2018). “How should companies that receive R\&D\&I funds communicate? Legal requirements in Spain”. El profesional de la información, v. 27, n. 3, pp. $633-640$. http://doi.org/10.3145/epi.2018.may.16

Wijnhoven, Fons; Ehrenhard, Michel; Kuhn, Johannes (2015). “Open government objectives and participation motivation". Government information quarterly, v. 32, n. 1, pp. 30-42.

https://doi.org/10.1016/j.giq.2014.10.002

Wirtz, Bernd W.; Birkmeyer, Steve (2015). "Open government: origin, development, and conceptual perspectives". International journal of public administration, v. 38, n. 5, pp. 381-396.

https://doi.org/10.1080/01900692.2014.942735

Wu, Weiwei; Liu, Yexin; Zhang, Qi; Yu, Bo (2019). “How innovative knowledge assets and firm transparency affect sustainability-friendly practices". Journal of cleaner production, v. 229, pp. 32-43.

https://doi.org/10.1016/j.jclepro.2019.05.007

Xu, Jian; Liu, Feng; Chen, You-hua (2019). “R\&D, advertising and firms' financial performance in South Korea: does firm size matter?". Sustainability, v. 11, n.14.

https://doi.org/10.3390/su11143764

Ye, Chen; Jha, Sanjeev; Desouza, Kevin C. (2015). "Communicating the business value of innovation”. International journal of innovation science, v. 7, n. 1, pp. 1-11.

https://doi.org/10.1260/1757-2223.7.1.1

Zhong, Rong-Irene (2018). "Transparency and firm innovation”. Journal of accounting and economics, v. 66, n. 1, pp. 67-93. https://doi.org/10.1016/j.jacceco.2018.02.001

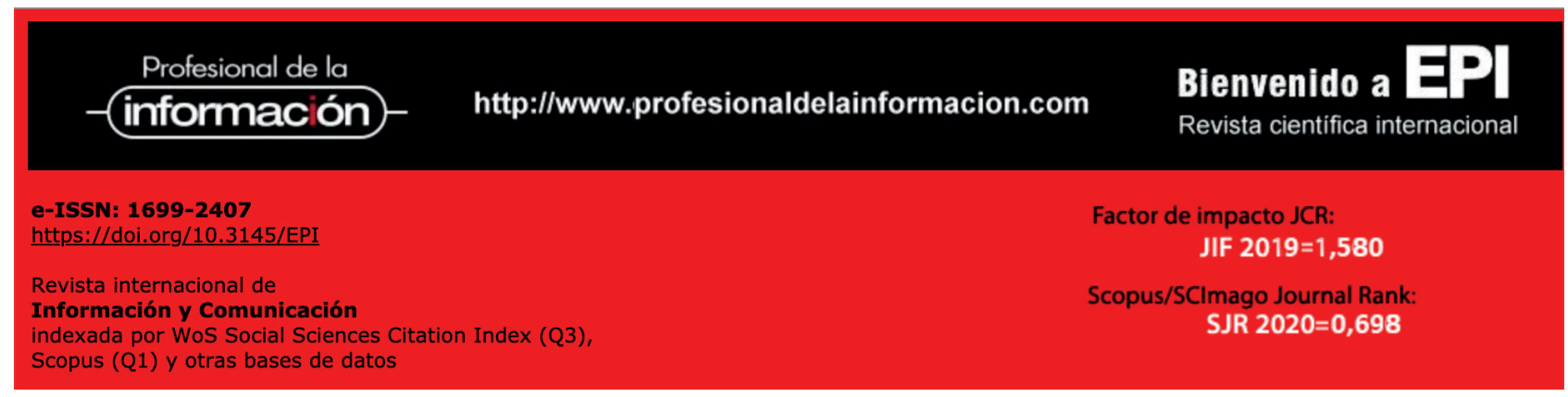

